\title{
Monogenetic osteoporosis: Does the risk of fall matter?
}

\author{
Mihai Cristian Dumitrascu ${ }^{1,2}$, Diana Elena Becheru ${ }^{3}$, Anda Dumitrascu ${ }^{3}$, Eugenia Petrova ${ }^{1,3}$, \\ Gabriela Voicu ${ }^{3}$, Adina Ghemigian ${ }^{1,3}$, Mihaela Popescu ${ }^{4}$, Mara Carsote ${ }^{1,3}$, Florica Sandru ${ }^{1,5}$ \\ 1"Carol Davila" University of Medicine and Pharmacy, Bucharest, Romania \\ 2University Emergency Hospital, Bucharest, Romania \\ 3"C.I. Parhon" National Institute of Endocrinology, Bucharest, Romania \\ ${ }^{4}$ Craiova University of Medicine and Pharmacy, Craiova, Romania \\ ${ }^{5}$ Elias Emergency Hospital, Bucharest, Romania
}

\begin{abstract}
We introduce an adult male case report with a history of osteogenesis imperfecta related fractures without specific medication against osteoporosis until the age of 50 years; however, within the first year he was offered anti-osteoporotic medication, he suffered a fall and a consecutive fracture was registered despite improved of bone mineral density parameters at DXA (dual-energy $x$-ray absorbtiometry), proving the importance of life style intervention to minimize the dramatic impact on bone fragility due to a genetic condition. Despite the fact that the risk of fracture on a subject with a genetic condition that directly impacts the bone status represents a game changer, the everyday circumstantial situations that cause an increased risk of fall represent strong players that need to be taken into consideration as part of patients' education.
\end{abstract}

Keywords: osteoporosis, osteogenesis imperfecta, risk of fall, fracture, DXA, endocrine osteoporosis, male osteoporosis, collagen, bone mineral density, Z-score

\section{BACKGROUND}

Osteoporotic fractures are related to a large area of endocrine conditions, including metabolic disturbances of glucose control, adipose tissue, calcium metabolism, or adrenal, pituitary and thyroid diseases, either directly related to hormonal imbalance like excess of cortisol, thyroid hormones, growth hormone etc., or indirectly associated to metabolic anomalies like those seen in diabetes mellitus (1-5). Under these circumstances, male osteoporosis represents a significant part of the chapter $(6,7)$. Other causes of male low - trauma fractures are represented by glucocorticoid excess exposure, hypogonadism (regardless if is age - related or not) and monogenetic osteoporosis underlying different bone anomalies like collagen damage as seen in osteoporosis imperfecta $(8,9)$.

\section{CASE PRESENTATION}

We introduce a male case report with a history of osteogenesis imperfecta related fractures with- out specific medication against osteoporosis until the age of 50 years; however, within the first year he was offered anti-osteoporotic medication, he suffered a fall and a consecutive fracture was registered despite improved of bone mineral density parameters at DXA (Dual-Energy X-Ray Absorbtiometry), proving the importance of life style intervention to minimize the dramatic impact on bone fragility due to a genetic condition. The patient agreed to anonymously use the medical records.

This is 51-year-old, non-smoker male who is admitted for bone status assessment. The personal medical history includes: osteogenesis imperfecta with multiple fragility fractures. The most recent was in November 2020, a leg fracture, while he was during his first year of therapy with weekly alendronate (70 $\mathrm{mg} /$ week) in addition to vitamin D supplements $(5,600 \mathrm{U} /$ week). The circumstances of fall were related to a mild episode of vertigo, apparently not a seizure, which were not associated to blood pressure and glycaemia variations. Orthopedic surgery was necessary and the patient's recovery went 
relatively well. He also associates a prior diagnostic of arterial hypertension (II ESH-ESC - currently under medication) and mild hypercholesterolemia.

Current evaluation indicates no glucose profile anomalies, with intact kidney function and mild liver enzymes anomalies (Table 1). In order to explore other potential causes of fall, the blood count was normal, excluding a severe anemia. Endocrine panel showed a correction of hypovitaminosis D (under supplementation) (Table 2). No hormonal anomalies are identified. The blood bone turnover markers showed a mild increase of bone formation marker osteocalcin of $45.66 \mathrm{ng} / \mathrm{ml}$ (normal values between 14 and $42 \mathrm{ng} / \mathrm{ml}$ ), and a mild increase of total alkaline phosphatase of $158 \mathrm{U} / \mathrm{l}$ (normal values between 38 and 129 U/l) (Table 2). Screening profile $\mathrm{X}$-Ray showed no fractures at thoracic and lumbar spine regions. Central DXA scan showed a good evolution profile since last evaluation (Table 3).

TABLE 1. The biochemistry panel on a 51-year old patient with osteogenesis imperfecta

\begin{tabular}{|c|c|c|c|}
\hline Parameter & Value & Normal ranges & Units \\
\hline Uric acid & 6.2 & $3.5-7.2$ & $\mathrm{mg} / \mathrm{dl}$ \\
\hline ALT & 16.4 & $0-41$ & $\mathrm{U} / \mathrm{I}$ \\
\hline AST & 39.9 & $0-38$ & $\mathrm{U} / \mathrm{I}$ \\
\hline Ionic calcium & 3.8 & $3.9-4.9$ & $\mathrm{mg} / \mathrm{dl}$ \\
\hline Total calcium & 8.9 & $8.5-10.2$ & $\mathrm{mg} / \mathrm{dl}$ \\
\hline total cholesterol & 210 & $0-200$ & $\mathrm{mg} / \mathrm{dl}$ \\
\hline phosphorus & 4 & $2.3-4.7$ & $\mathrm{mg} / \mathrm{dl}$ \\
\hline fasting glucose & 87.5 & $70-110$ & $\mathrm{mg} / \mathrm{dl}$ \\
\hline HDL-cholesterol & 93 & $40-60$ & $\mathrm{mg} / \mathrm{dl}$ \\
\hline LDL-cholesterol & 108 & $60-160$ & $\mathrm{mg} / \mathrm{dl}$ \\
\hline Potassium & 4.5 & $3.5-5.1$ & $\mathrm{mmol} / \mathrm{l}$ \\
\hline Magnesium & 1.76 & $1.6-2.55$ & $\mathrm{mg} / \mathrm{dl}$ \\
\hline Sodium & 142 & $136-145$ & $\mathrm{mmol} / \mathrm{l}$ \\
\hline Total proteins & 7.4 & 6.4-8.3 & $\mathrm{g} / \mathrm{dl}$ \\
\hline Triglycerides & 49 & $0-149$ & $\mathrm{mg} / \mathrm{dl}$ \\
\hline Urea & 21.6 & $15-50$ & $\mathrm{mg} / \mathrm{dl}$ \\
\hline Creatinine & 0.62 & $0.5-1.2$ & $\mathrm{mg} / \mathrm{dl}$ \\
\hline 24-hour urinary calcium & 0.03 & $0.07-0.3$ & $g / 24 \mathrm{~h}$ \\
\hline
\end{tabular}

TABLE 3. Adult male with osteogenesis imperfecta and a history of fragility fractures: DXA scan at first evaluation and after one year of daily alendronate $70 \mathrm{mg}$ in association with vitamin D supplementation

\begin{tabular}{|l|l|c|c|c|}
\hline Year & Regions & Z-score (SD) & BMD $\mathbf{( g / \mathbf { c m } ^ { 2 } )}$ & TBS \\
\hline \multirow{3}{*}{2020} & L1-4 & -2.9 & 0.776 & NA \\
\cline { 2 - 5 } & femoral neck & -0.2 & 0.928 & \\
\cline { 2 - 5 } & total hip & -0.9 & 0.882 & \\
\cline { 2 - 5 } & $\begin{array}{l}\text { 1/3 distal } \\
\text { radius }\end{array}$ & 0.05 & 0.848 & \\
\hline 2021 & L1-4 & -2.2 & 0.874 & 1.262 \\
\cline { 2 - 5 } & femoral neck & 0.1 & 0.965 & \\
\cline { 2 - 5 } & total hip & -0.7 & 0.916 & \\
\cline { 2 - 5 } & $\begin{array}{l}\text { 1/3 distal } \\
\text { radius }\end{array}$ & 0.7 & 0.860 & \\
\hline
\end{tabular}

*BMD = bone mineral density; $L=$ lumbar

The patient was offered a $5 \mathrm{mg}$ dose of zolendronic acid/year and he continued with vitamin D supplements.

In order to evaluate the risk of fall with particularly dangerous complications on bone status, cerebral computed tomography imaging was done, and, except for cerebral atheromatosis, no special pathology was revealed, considering the short episode of vertigo that the patient described (Figure 1). Lifelong follow-up is necessary.

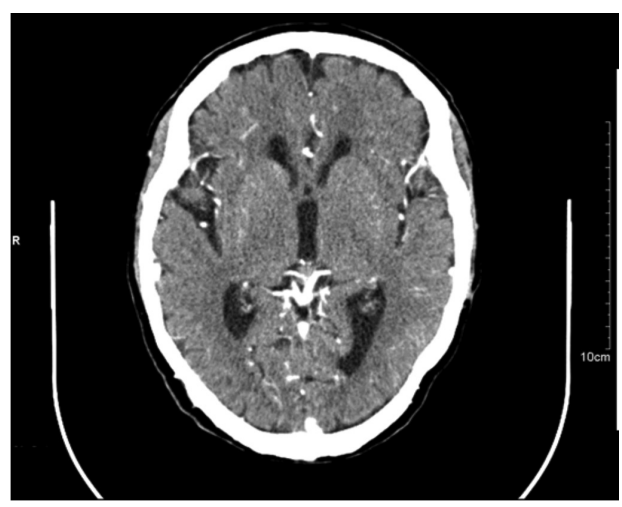

FIGURE 1. 51-year-old male with a history of fall related to a short episode of vertigo: cerebral computed tomography scan; no particular cause of fall is identified

TABLE 2. Endocrine panel and blood bone turnover markers on a 51-year old osteoporotic patient with a recent fragility fracture (the data are introduced at first moment the anti-osteoporotic medication was started, respectively in February 2020, and the latest assessment, respectively in August 2021)

\begin{tabular}{|l|l|l|l|l|}
\hline Parameter & Value February 2020 & Value August 2021 & Normal ranges & Units \\
\hline TSH (thyroid stimulating hormone) & 0.58 & 0.9 & $0.5-4.5$ & $\mathrm{microUl} / \mathrm{ml}$ \\
\hline FT4 (free levothyroxine) & 15.16 & 13.04 & $9-19$ & $\mathrm{pmol} / \mathrm{l}$ \\
\hline ATPO (anti thyroperoxidase antibodies) & NA & 0.24 & $0-5.61$ & $\mathrm{UI} / \mathrm{ml}$ \\
\hline 25OHD (25-hydroxyvitamin D) & 10.2 & 42.8 & $30-100$ & $\mathrm{ng} / \mathrm{ml}$ \\
\hline Blood calcitonine & 11.22 & 7.24 & $8.31-14.3$ & $\mathrm{pg} / \mathrm{ml}$ \\
\hline CrossLaps & 0.2 & 0.56 & $0.158-0.442$ & $\mathrm{ng} / \mathrm{ml}$ \\
\hline Osteocalcin & 20.8 & 45.66 & $14-42$ & $\mathrm{ng} / \mathrm{ml}$ \\
\hline P1NP & 36.78 & 53.21 & $15.13-58.59$ & $\mathrm{ng} / \mathrm{ml}$ \\
\hline Parathormone & 26.53 & 26.42 & $15-65$ & $\mathrm{pg} / \mathrm{ml}$ \\
\hline FSH (follicle stimulating hormone) & NA & 8.2 & $1.5-12.4$ & $\mathrm{mlU} / \mathrm{ml}$ \\
\hline Total plasma testosterone & 4.05 & 4.26 & $1.93-7.4$ & $\mathrm{ng} / \mathrm{ml}$ \\
\hline
\end{tabular}




\section{DISCUSSION}

We mention three topics related to this case. The first one is the fact that in adults with osteogenesis imperfecta, with or without medication, a dramatic impact on fractures is presented lifelong, regardless circumstances of daily life, because of genetic alteration of collagen structure $(10,11)$. However, a particular intervention of daily habits is required. In this case, the arterial hypertension and spontaneous episode of vertigo might have been a collateral cause of fall. Situational risk factors, as displayed in Figure 2, are key elements in osteoporotic patients' education, considering a particular high risk of osteoporotic fractures (12). Another topic is associated to the question which is the best selection of mediation against osteoporosis on an adult male with osteogenesis imperfecta suffering a new fracture; a part from bisphosphonates, and denosumab, romosozumab utility is yet to be determined $(13,14,15)$.

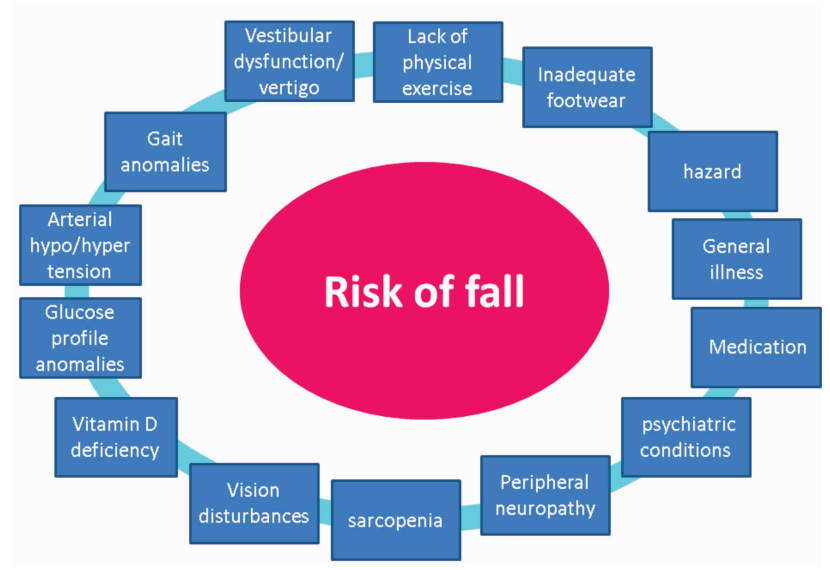

FIGURE 2. Potential circumstances related to the risk of fall (12)

We also mention the fact that the patient' son inherited his condition. The first evaluation for osteoporosis was done in 2020, at the age of 27 years; he never received any medication against osteoporosis as a child or teenager, also suffering of multiple

\section{REFERENCES}

1. Sandru F, Dumitrascu MC, Albu SE, Carsote M, Valea A. Obesity and osteoporotic fractures. Romanian Journal of Military Medicine. 2020;123(30):166-171.

2. Sandru F, Dumitrascu MC, Albu SE, Carsote M, Valea A. Osteoporosis and adrenal incidentaloma: To be or not to be? Ro J Med Pract. 2019; 14(4):381-4

3. Paduraru DN, Ion D, Carsote M, Andronic O, Bolocan A. Postthyroidectomy Hypocalcemia - Risk Factors and Management. Chirurgia. 2019;114(5):564-570.

4. Valea A, Carsote M, Ghervan C, Georgescu C. Glycemic profile in patients with acromegaly treated with somatostatin analogue. J Med Life. 2015;8(Spec issue):79-83. fractures. He also started medication with alendronate $70 \mathrm{mg} /$ week and 5,600 U/week without a new fracture during the first year of this regime (Table 4 and Table 5).

TABLE 4. 27-year old male with osteogenesis imperfecta: bone metabolism evaluation

\begin{tabular}{|l|l|l|l|l|}
\hline Parameter & $\begin{array}{l}\text { Value } \\
\text { February } \\
\mathbf{2 0 2 0}\end{array}$ & $\begin{array}{l}\text { Value } \\
\text { August } \\
\mathbf{2 0 2 1}\end{array}$ & $\begin{array}{l}\text { Normal } \\
\text { ranges }\end{array}$ & units \\
\hline 25OHD & 13.3 & 30.4 & $30-100$ & $\mathrm{ng} / \mathrm{ml}$ \\
\hline calcitonin & 4.2 & 4.01 & $8.31-14.3$ & $\mathrm{pg} / \mathrm{ml}$ \\
\hline CrossLaps & 0.49 & 0.51 & $0.158-0.442$ & $\mathrm{ng} / \mathrm{ml}$ \\
\hline Osteocalcin & 51.09 & 57.06 & $24-70$ & $\mathrm{ng} / \mathrm{ml}$ \\
\hline P1NP & 43.13 & 43.13 & $15.13-58.59$ & $\mathrm{ng} / \mathrm{ml}$ \\
\hline Parathormone & 34.43 & 33.99 & $15-65$ & $\mathrm{pg} / \mathrm{ml}$ \\
\hline
\end{tabular}

TABLE 5. The measurements done with GE Lunar Prodigy central DXA device: 26-year old patient with ostegenesis imperfecta and an associated history of multiple pediatric fragility fractures

\begin{tabular}{|c|c|c|c|c|}
\hline & Region & Z-score (SD) & $\mathrm{BMD}\left(\mathrm{g} / \mathrm{cm}^{2}\right)$ & TBS \\
\hline \multirow[t]{4}{*}{2020} & Lumbar L1-4 & -4 & 0.689 & NA \\
\hline & femoral neck & -0.5 & 0.988 & \\
\hline & total hip & -0.2 & 1.028 & \\
\hline & $1 / 3$ distal radius & -1.5 & 0.685 & \\
\hline \multirow[t]{4}{*}{2021} & Lumbar L1-4 & -4 & 0.699 & 1.228 \\
\hline & femoral neck & 0.6 & 0.968 & \\
\hline & total hip & -0.6 & 0.978 & \\
\hline & $1 / 3$ distal radius & -1.5 & 0.687 & \\
\hline
\end{tabular}

*bmd=bone mineral density

\section{CONCLUSIONS}

Despite the fact that the risk of fracture on a subject with a genetic condition that directly impacts the bone status represents a game changer, the everyday circumstantial situations that cause an increased risk of fall represent strong players that need to be taken into consideration as part of patients' education.

Conflict of interest: none declared Financial support: none declared

5. Valea A, Ghervan C, Carsote M, Morar A, lacob I, Tomesc F, Po DD, Georgescu C. Effects of combination therapy: somatostatin analogues and dopamine agonists on GH and IGF1 levels in acromegaly. Clujul Medical. 2015;88(3):310-313.

6. Hu J, Zheng W, Zhao D, Sun L, Zhou B, Liu J, Wang O, Jiang Y, Xia W, Xing $X$, Li M. Health-related quality of life in men with osteoporosis: a systematic review and meta-analysis. Endocrine. 2021 Jun 24.

7. Ross BJ, Lee OC, Harris MB, Dowd TC, Savoie FH 3rd, Sherman WF. Rates of Osteoporosis Management and Secondary Preventative Treatment After Primary Fragility Fractures. JB JS Open Access. 2021 Jun 14;6(2):e20.00142. 
8. Sandru F, Carsote M, Dumitrascu MC, Albu SE, Valea A. Glucocorticoids and Trabecular Bone Score. Journal of Medicine and Life.

2020;13(4):449-53.

9. Carsote M, Sandru F, Albu SE, Dumitrascu MC, Petrova E, Valea A. Skin aging: neuroendocrine challange. Ro Med J. 2020;67(1):27-30.

10. Mäkitie RE, Costantini A, Kämpe A, Alm JJ, Mäkitie O. New Insights Into Monogenic Causes of Osteoporosis. Front Endocrinol (Lausanne). 2019 Feb 25;10:70.

11. Mäkitie O, Zillikens MC. Early-Onset Osteoporosis. Calcif Tissue Int. 2021 Jul 8.

12. Yu WY, Hwang HF, Chen CY, Lin MR. Situational risk factors for fall-related vertebral fractures in older men and women. Osteoporos Int. 2021 Jun;32(6):1061-1070.
13. Anastasilakis AD, Makras P, Doulgeraki A, Polyzos SA, Guarnieri V, Papapoulos SE. Denosumab for the treatment of primary pediatric osteoporosis. Osteoporos Int. 2021 May 13.

14. Ward LM. Part 2: When Should Bisphosphonates Be Used in Children with Chronic Illness Osteoporosis? Curr Osteoporos Rep. 2021 Jun;19(3):289-297.

15. Uehara M, Nakamura Y, Nakano M, Miyazaki A, Suzuki T, Takahashi J. Efficacy of Romosozumab for Osteoporosis in a Patient With Osteogenesis Imperfecta: A Case Report. Mod Rheumatol Case Rep. 2021 Aug 28:rxab018. 